\title{
CORRECTION
}

Open Access

\section{Correction to: Nongenomic oestrogen signalling in oestrogen receptor negative breast cancer cells: a role for the angiotensin II receptor AT1}

Kheng Tian Lim', Niamh Cosgrave ${ }^{1}$, Arnold David Hill ${ }^{1,2}$ and Leonie S. Young ${ }^{1 *}$

\section{Correction}

After the publication of this work [1] errors were noticed in the total protein loading controls for Figs. 1C, 2B, 3B and $4 \mathrm{~B}$. These errors do not affect the interpretation of the data. The corrected figures are shown below. We apologize for this error.

\begin{abstract}
Author details
${ }^{1}$ School of Medicine and Medical Science, St. Vincent's University Hospital, Elm Park, Dublin, Ireland. ${ }^{2}$ School of Medicine and Medical Science, UCD Conway Institute of Biomolecular and Biomedical Research, UCD Conway Institute, University College Dublin, Dublin, Ireland.
\end{abstract}

Received: 14 May 2018 Accepted: 14 May 2018

Published online: 20 June 2018

\section{Reference}

1. Lim KT, Cosgrave N, Hill AD, Young LS. Nongenomic oestrogen signalling in oestrogen receptor negative breast cancer cells: a role for the angiotensin II receptor AT1. Breast Cancer Res. 2006;8(3):R33.

\footnotetext{
*Correspondence: lyoung@rcsi.ie

'School of Medicine and Medical Science, St. Vincent's University Hospital,

Elm Park, Dublin, Ireland
} 

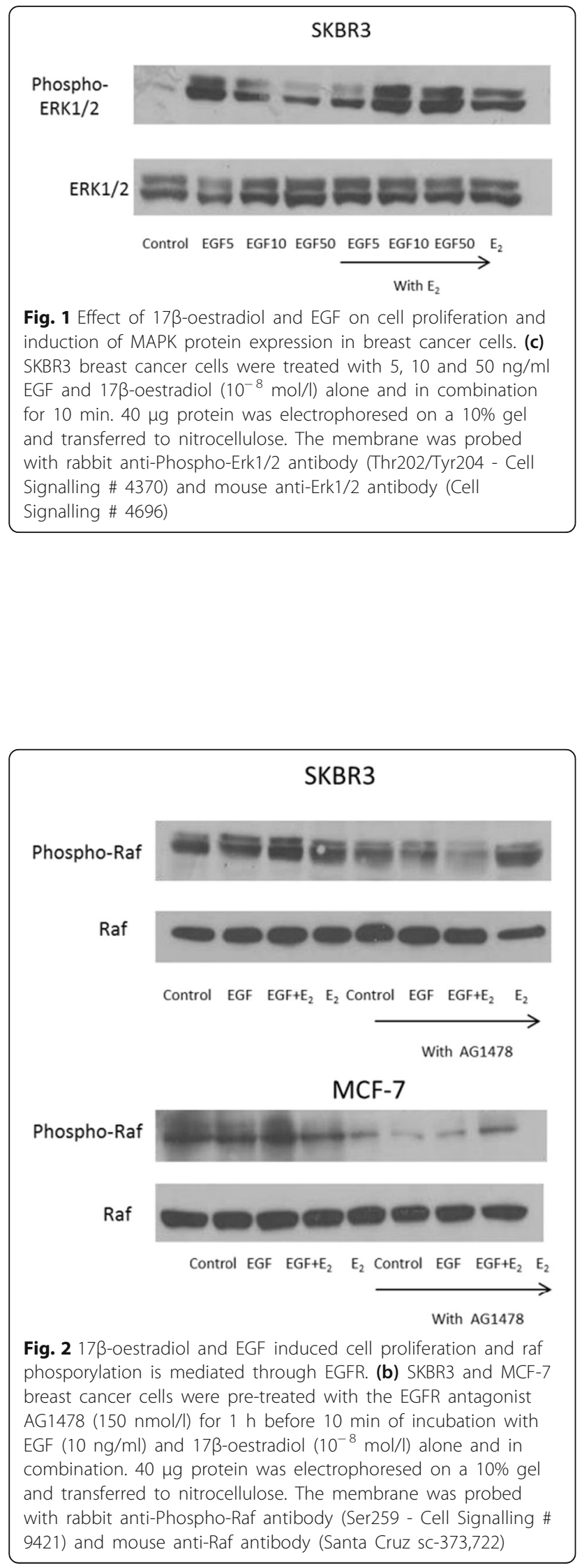
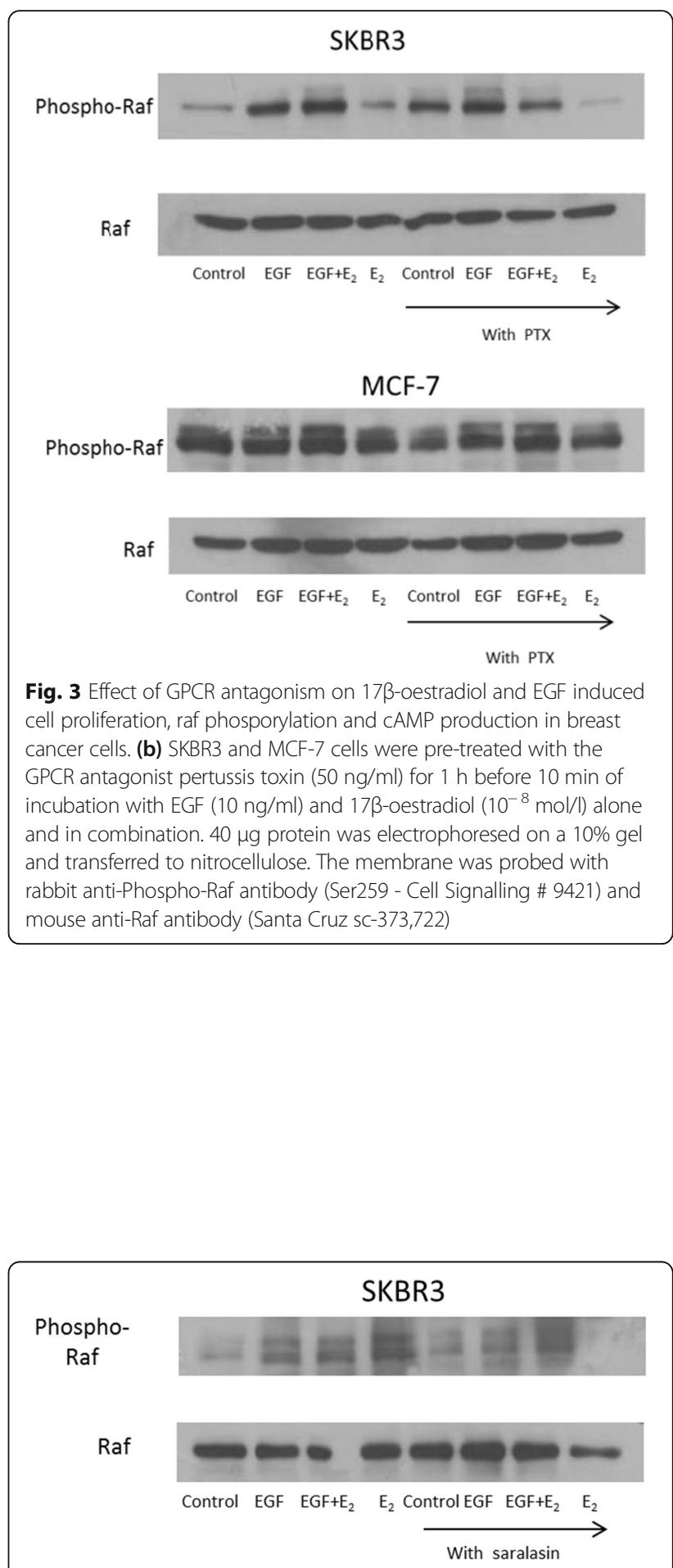

Fig. 4 The role of the AT1 receptor in 17ß-oestradiol and EGF mediated cell proliferation and raf phosphorylation breast cancer cells. (b) SKBR3 cells were pre-treated with the AT1 antagonist saralasin $\left(10^{-6} \mathrm{~mol} / \mathrm{l}\right)$ for $1 \mathrm{~h}$ before $10 \mathrm{~min}$ of incubation with EGF $(10 \mathrm{ng} / \mathrm{ml})$ and $17 \beta$-oestradiol $\left(10^{-8} \mathrm{~mol} / \mathrm{l}\right)$ alone and in combination. $40 \mathrm{\mu g}$ protein was electrophoresed on a $10 \% \mathrm{gel}$ and transferred to nitrocellulose. The membrane was probed with rabbit anti-Phospho-Raf antibody (Ser259 - Cell Signalling \# 9421) and mouse anti-Raf antibody (Santa Cruz sc-373,722) 